IZA DP No. 7159

Gender Wage-Productivity Differentials and Global Integration in China

Ana C. Dammert

Beyza Ural Marchand

Chi Wan

January 2013 


\title{
Gender Wage-Productivity Differentials and Global Integration in China
}

\author{
Ana C. Dammert \\ Carleton University and IZA \\ Beyza Ural Marchand \\ University of Alberta \\ Chi Wan \\ University of Massachusetts
}

Discussion Paper No. 7159
January 2013

IZA
P.O. Box 7240
53072 Bonn
Germany

Phone: +49-228-3894-0

Fax: +49-228-3894-180

E-mail: iza@iza.org

\begin{abstract}
Any opinions expressed here are those of the author(s) and not those of IZA. Research published in this series may include views on policy, but the institute itself takes no institutional policy positions. The IZA research network is committed to the IZA Guiding Principles of Research Integrity.

The Institute for the Study of Labor (IZA) in Bonn is a local and virtual international research center and a place of communication between science, politics and business. IZA is an independent nonprofit organization supported by Deutsche Post Foundation. The center is associated with the University of Bonn and offers a stimulating research environment through its international network, workshops and conferences, data service, project support, research visits and doctoral program. IZA engages in (i) original and internationally competitive research in all fields of labor economics, (ii) development of policy concepts, and (iii) dissemination of research results and concepts to the interested public.
\end{abstract}

IZA Discussion Papers often represent preliminary work and are circulated to encourage discussion. Citation of such a paper should account for its provisional character. A revised version may be available directly from the author. 


\section{ABSTRACT \\ Gender Wage-Productivity Differentials and Global Integration in China*}

In the absence of discrimination, there should be no wage-productivity differentials as relative wages should be equal to the relative marginal productivity levels of workers. This paper investigates the role of globalization on the structure and evolution of gender differentials in China by simultaneously estimating demand-side wage and productivity outcomes using nonlinear least squares. The analyses are based on a comprehensive population-wide panel survey of manufacturing firms between the years of 2004 and 2007, covering 94 percent of total industry output and providing an accurate representation of labor demand. The results suggest that more exposure to globalization through increased exports is associated with lower gender wage-productivity differentials, and more exposure through increased foreign investment leads to differentials in favor of female workers. On the other hand, gender discrimination is found to be prevalent among domestically owned and non-exporting firms.

JEL Classification: D22, F21, F61, J16, J31

Keywords: China, gender wage discrimination, globalization, firm ownership

Corresponding author:

Beyza Ural Marchand

University of Alberta

Department of Economics

7-12 Tory Building

Edmonton, AB, T6G 2H4

Canada

E-mail: beyza.ural@ualberta.ca

\footnotetext{
* The authors gratefully acknowledge financial support from the Social Sciences and Humanities Research Council of Canada (SSHRC). In addition, we would like to thank Professor Jun Shao from Southeast University (China) for providing the data. Any errors and omissions are our own.
} 


\section{Introduction}

Many developing countries have undergone substantial reforms to liberalize their domestic industries and integrate these industries with the global trade and finance systems. The studies that investigate the impact of these reforms on the relative status of women offers a wide range of evidence varying from significant improvements to significant deterioration. This literature primarily relies on supplyside employment surveys, and identifies the residual gender wage gaps that cannot be explained by human capital characteristics as employer discrimination. The demand-side factors, such as productivity-related characteristics of the firms, are often overlooked. If the female workers are clustered into firms that has relatively low marginal product of labor inputs, this may be interpreted as gender discrimination as the wage regressions often do not account for characteristics of the labor demand. In addition, the supply-side determinants of worker productivity tend to be incomplete as they do not contain the unobserved characteristics of workers, which may cause misleading results if the distribution of these characteristics are not identical between female and male workers.

In this paper, we estimate gender wage-productivity differentials in China in order to investigate the impact of globalization on the structure of worker compensation, worker productivity, and the gender differentials between these outcomes using a firm-level panel survey from post-reform China. The methodology in this paper follows Dong and Zhang (2009), who compares gender wage ratios to productivity ratios, and offers the most direct demand-side evidence using firm level data. Although they estimate each of these outcomes independently, ignoring the simultaneity between these two outcomes can lead to biased estimates, as the unobserved characteristics of workers tend to affect both productivity and wage compensation in a similar manner. Thus, the first contribution of this paper is an improvement upon this methodology, incorporating a mechanism that jointly determines wage and productivity outcomes. While the previous literature was based on small-sample cross-sectional data, this paper also makes a contribution by providing the first evidence based on a unique population-wide firm-level panel survey that covers all state-owned firms and all private firms with sales over 5 million RMB. Using the panel aspect of this data, we not only assess the average gender wage-productivity differentials, but more importantly, gauge whether and 
how such an effect changes over time by distinguishing between firms that are integrated with the global economy from firms that instead primarily target the domestic market.

China is an important country to study the relationship between globalization and gender outcomes. In addition to being home to approximately 20 percent of the world's population, it is a top destination for foreign direct investment and a world power in the exporting of unskilled labor intensive goods. ${ }^{1}$ Since 1979, the Chinese government has enthusiastically promoted international trade and foreign direct investment inflows. As a result, China's international trade has expanded over 75 times from 1979 to 2009. ${ }^{2}$ By 2010, China was the second-largest importer and had overtaken Germany as the world's largest merchandise exporter, currently accounting for almost 10 percent of total world exports (WTO, 2010 press releases). Foreign direct investment, as a driving force of economic globalization, has further strengthened China's integration into the global economy. In particular, foreigninvested enterprises account for over 50 percent of China's exports and 60 percent of China's imports, contributing to over 40 percent of China's GDP growth in 2003 and 2004 (Whalley and Xin, 2006). In 2009, China registered $\$ 90$ billion of foreign direct investment inflows despite the global economic downturn and was ranked as the world's second-largest foreign direct investment recipient.

Despite the significance of China, the effect of global integration on Chinese women is not yet clear. Some studies have found that gender wage gaps and discrimination have declined substantially over time (Liu et al., 2000), and that these gaps were smaller in China than in other developing countries (Gustafson and Li, 2000; Maurer-Faizo et al., 1999). In contrast, other researchers found that the disparity between male and female workers had widened during economic reforms (Maurer-Fazio et al., 1999; Bishop et al., 2005; Xu, 2006), and while relative labor demand shifted towards female workers, their earnings grew much slower than that of male workers (Gao et al., forthcoming; Zhihong et al.,2012). Dong and Zhang (2009) point out that unskilled female workers have historically received wage premiums, and that gender wage gaps have been substantially lower in state-owned

\footnotetext{
${ }^{1}$ World Development Indicators, 2011.

${ }^{2}$ In 1979, China's trade with the world was $\$ 29.234$ billion. This total increased to $\$ 2207.2$ billion in 2009. Source: International Financial Statistics Yearbook and China's Customs Statistics.
} 
enterprises. The liberalization of domestic markets and the privatization reform may have increased wage disparity by removing these premiums. On the other hand, there is also a strand of literature which have found that these economic reforms had no significant impact on gender gaps (Rozelle et al., 2002; Shu and Bian, 2003).

The results of the current paper suggest that the average wages of female workers are approximately 78 percent of that of males among exporting firms, indicating a significant gender wage gap. However, this gender wage ratio is equivalent to the gender marginal productivity ratio, which is estimated to be around 77 percent. As a result, we do not find evidence of discrimination among exporters. Among foreign-invested firms, while the relative wage of women is much lower at 69 percent, the relative productivity of female workers is 39 percent, indicating that the relative wages of female workers are in fact larger than their relative marginal productivity would suggest. These results hold across the spectrums of export intensity and the share of foreign investment, and in most cases, over time as well. Non-exporting and domestic firms pay female workers significantly lower than their relative marginal product, indicating discrimination. In addition, we find that both the relative wages and relative productivity levels of female workers improved among exporters and deteriorated among state-owned firms, even though the discrimination tests were rejected for both types of firms. Overall, the results show that globally integrated firms tend to pay female workers equal to their relative marginal product or higher, while discrimination is found to be more prevalent among domestically-oriented firms. Our findings suggest that, while female wages are lower than male wages across the country, globalization has not contributed to gender discrimination in China over this recent period.

The paper is organized as follows. Section 2 provides a review of related literature while Section 3 describes the methodology and Section 4 describes the data. Wage and productivity differentials are investigated in Section 5 and Section 6 concludes the paper.

\section{Related Literature}

How does globalization impact gender wage differentials? Despite numerous contributions to this growing literature, a consensus among researchers has yet to 
be reached. The more prevailing strand asserts that globalization reduces gender wage differentials. Following the seminal work of Becker (1957) on the economics of discrimination, many argue that globalization leads to increasing competitive pressures and therefore increases the costs of labor market discrimination. Thus, market forces might reduce and even eliminate gender wage discrimination in the long run (Black and Brainerd, 2004; Menon and Rodgers, 2008).

In addition to the reduction in gender differentials by increased competition, neoclassical trade theory predicts that trade increases the relative wages of unskilled workers in developing countries. Expansion in the export-oriented sectors is likely to have positive effects on the demand for relatively abundant, low-skilled labor, and is also likely to reduce wage differentials between skilled and unskilled workers. International trade has gender-specific effects when the skill distributions of male and female workers are not identical. In most developing countries, low-skill intensive export industries, such as textile, clothing, footwear, and toys, are overwhelmingly dominated by females (Nordas, 2003). Because women are clustered in low-skilled sectors and men are clustered in high-skilled sectors, the trade-induced increase in demand for unskilled labor should increase women's relative wages and reduce the gender wage gap (Standing, 1999; Ozler, 2000; Wood, 1991).

Although it is evident that there is a considerable amount of job segregation, it is not yet clear whether females are working in these sectors by choice or due to a lack of job market opportunities (Busse and Spielman, 2006; Cohen and House, 1993; Seguino, 2000). Some of this literature argues that women are employed in these sectors because they have a comparative advantage in the production of export goods. Especially in East Asian countries, some of the export-oriented sectors are relatively more knowledge intensive. This gives female workers a relative advantage over male workers, as compared with the other sectors that require physical power. Evidence shows that gender wage differentials in knowledge-based industries decreased much faster than their non-knowledge-based counterparts (Berik, Rodgers, and Zveglich, 2004; Ural et al., 2009), although the gender wage gaps in the manufacturing sector continued to be consistently high over time (Segiuno, 1997).

These benefits to women in the export-oriented sectors are not sustainable in the long run if they are not accompanied by an improvement in human capital 
investment. The proportion of employed women declined in the export processing zones in Malaysia, Korea, and the Philippines (Joekes, 1995), and in exportoriented industries in India, Singapore, and Turkey (Braunstein, 2006). Whether these women have moved to better local alternatives or whether they were instead displaced due to increasing demand for skill in export-oriented sectors has yet to be studied. Nevertheless, women in export-oriented sectors earn significantly more than women in other sectors (Malchow-Moller et al., 2009), implying that the former alternative is more likely, and that the growth in women's educational investment was slower than the increased demand for skill among export-oriented firms.

The other branch of the literature sensibly argues that globalization increases gender wage differentials. A large influx of female labor from households to foreigninvested and export-oriented industries, that generally use more unskilled labor and offer higher compensation, may cause a surplus in female labor and widen the wage gap in developing countries. Such adverse effects of globalization may be further worsened as male and female workers compete to meet the rising demand for cheap labor and thus hold down one another's wages (Seguino, 2005). Moreover, a widening segregation in the labor force may lock females into low-wage sectors, reducing incentives for human capital investment and thus creating a gender gap in educational attainment. If the expansion of sectors in which females have a relative advantage is accompanied by a contraction in other sectors, there may be an inflow of male workers into female relative advantage industries, thereby decreasing the marginal productivity of female workers and increasing the gender wage gap (Suare and Zaobi, 2009).

The widely used Hecksher-Ohlin model in the international trade and gender literature assumes perfect competition and perfect inter-sectoral labor mobility. This theory predicts that the wages of workers with the same skills should equalize across industries and across all firms within an industry. This view is not verified by the empirical evidence, however. ${ }^{3}$ The perfect labor mobility assumption is likely to be violated as the labor market regulations in most developing countries prevent workers from efficiently reallocating across sectors (Mitra and Ural, 2008). Imperfect labor mobility is particularly true for China, as the household registration system, known as hukou, significantly restricts rural-urban migration (Chan,

\footnotetext{
${ }^{3}$ See, for example, Attanasio et al. (2004) and Kruger and Summers (1988).
} 
2003; Lau, Liu, and Zhang, 1999).

The literature on inter-industry gender wage gaps points to significant differences across industries in developed countries (Abowd, 1999; Benito, 2000; Goux and Maurin, 1999) as well as in developing countries (Ural et al., 2009). These studies use various forms of decomposition to separate the portion of the gender wage gap which can be attributed to differences in human capital characteristics between male and female workers, from the unexplained portion which can be attributed to discrimination. These industry differences in the gender wage gaps imply that the building blocks of the neoclassical theory may be violated, and that one cannot consider gender effects of globalization independently of the market regulations within a country.

In import-competing sectors, trade liberalization in the form of tariff reductions and the removal of nontariff barriers can increase gender wage differentials. If trade protection was initially granted to unskilled-labor intensive industries, removal of this protection can reduce the relative wages of unskilled workers. Skill-biased technological change induced by globalization and the skill complementarity with capital goods or with imported inputs also reduce the relative wages of unskilled workers. In addition, if skilled workers possess more industry-specific human capital and their supply curve is less elastic than that of unskilled workers, then a shift in overall labor demand due to globalization would likely reduce the relative wages of unskilled workers (Galiani and Porto, 2010; Revenga, 1997). Because female workers are clustered in industries that are intensive in low-skill labor, these channels can disproportionately hurt female workers and increase gender wage differentials.

The theoretical ambiguity of these potentially contradictory effects of globalization on gender wage differentials is echoed by mixed the empirical evidence. Consistent with Becker's prediction, some empirical studies have documented that international trade and foreign direct investment have reduced the gender wage disparity, particularly in competitive manufacturing industries that are facing increased competition through globalization (Black and Brainerd, 2004; Fontana and Wood, 2000; Oostendorp, 2009). On the other hand, other papers have found that competition from international trade widens the gender wage gap (Berik et al., 2004), especially in expanding export-oriented sectors (Nicita and Razzaz, 2003; Cling et al., 2005). By comparing foreign firms to domestic firms, some scholars 
conclude that foreign firms discriminate more heavily against women relative to their domestic counterparts (Sequino, 1997). Therefore, while most studies indicate an overall reduction in gender wage discrimination through globalization, there are significant exceptions at the country level which demand further investigation.

\section{$3 \quad$ Methodology}

This section outlines a model of employer discrimination where the firm hires both male and female workers and offers a wage for each type of worker. Based on Hellerstein and Neumark (1999) and under the assumption of perfect competition, employer discrimination would be observed if wage premium paid to a worker did not equal its productivity premium. In this model, both premiums are identified by jointly estimating a wage equation and a production function. ${ }^{4}$

Assume that male and female workers are paid a wage of $W_{t}^{f}$ and $W_{t}^{m}$ in year $t$, respectively, but the average productivity of male workers differs from that of female workers by $\phi$. Thus, the average wage of a firm in year $t, W_{t}$ is a weighted average of the wages of female and male workers, specified as:

$$
W_{t}=W_{t}^{m} \frac{L_{t}^{m}}{L_{t}}+W_{t}^{f} \frac{L_{t}^{f}}{L_{t}}=W_{t}^{m}+\left(W_{t}^{f}-W_{t}^{m}\right) \frac{L_{t}^{f}}{L_{t}}
$$

where $L_{t}^{f}$ and $L_{t}^{m}$ are the share of female and male employment of the total labor force $L_{t}$ of a firm, respectively. The natural logarithm of the average wage yields:

$$
\ln W_{t}=\ln \left(W_{t}^{m}\right)+\ln \left[1+\left(\phi_{t}-1\right) \frac{L_{t}^{f}}{L_{t}}\right]
$$

where $\phi_{t}$ is the wage ratio of female and male workers, $W_{t}^{f} / W_{t}^{m}$. If $\phi_{t}<1$, then it implies that the wage of a female worker is lower than that of a male worker in

\footnotetext{
${ }^{4} \mathrm{~A}$ number of papers have applied this methodology to the analysis of gender discrimination in different countries. For example, Hellerstein and Neumark (1999) for Israel; Hellerstein, Neumark, and Troske (1999) for the U.S.; Verner (1999) for Ghana; Lopez-Acevedo et al. (2005) for Mexico; Van Biesebroeck (2012) for three Sub-Saharan countries; and Dong and Zhang (2009) for 998 firms located across five cities in China.
} 
year $t .^{5}$

In year $t$, the Cobb - Douglas production function is given by:

$$
Q=A(E L)^{\alpha} K^{\beta}
$$

where the time subscript is suppressed; $A$ is technical level, $Q$ is the output measured by value added; $K$ is the amount of capital, $L$ is the amount of labor; and $E$ is the average quality of labor. Similar to equation (1), the average quality of labor in year $t, E_{t}$ is the weighted average productivity of male and female workers.

$$
E_{t}=q_{t}^{m} \frac{L_{t}^{m}}{L_{t}}+q_{t}^{f} \frac{L_{t}^{f}}{L_{t}}=q_{t}^{m}+\left(q_{t}^{f}-q_{t}^{m}\right) \frac{L_{t}^{f}}{L_{t}}
$$

where $q_{t}^{f}$ is the productivity of female workers and $q_{t}^{m}$ is the productivity of male workers. The natural logarithm of average labor index yields:

$$
\ln \left(E_{t}\right)=\ln \left(q_{t}^{m}\right)+\ln \left[1+\left(\rho_{t}-1\right) \frac{L_{t}^{f}}{L_{t}}\right]
$$

where $\rho_{t}$ is the productivity ratio of male and female workers, $q_{t}^{f} / q_{t}^{m}$. If $\rho_{t}<1$, then it implies that women are less productive than men in year $t$.

The linear approximation of $\ln \left(W_{t}^{m}\right)$ and $\ln A_{t}+\ln \left(q_{t}^{m}\right)$ by various firm, industry, and regional variables yields the empirical estimating equations of (2) and (3) as follows:

$$
\begin{gathered}
\ln \left(W_{t}\right)=\lambda_{0}+\ln \left[1+\left(\phi_{t}-1\right) \frac{L_{t}^{f}}{L_{t}}\right]+X_{t}^{\prime} \lambda+u_{t} \\
\ln \left(Q_{t}\right)=\gamma_{0}+\alpha \ln \left[1+\left(\rho_{t}-1\right) \frac{L_{t}^{f}}{L_{t}}\right]+\alpha \ln \left(L_{t}\right)+\beta \ln \left(K_{t}\right)+Z_{t}^{\prime} \gamma+\nu_{t}
\end{gathered}
$$

We omitted the firm subscript for simplicity. $\lambda_{0}$ and $\gamma_{0}$ are constant terms, $\ln \left(W_{t}\right)$ is the logarithm of the average wage level of enterprises in year $t, L_{t}^{f}$ is the size

\footnotetext{
${ }^{5}$ We are unable to differentiate the skill level of workers, as in Dong and Zhang (2009), given that neither occupational categories nor educational attainment are available in our dataset as detailed in Section 4. Dong and Zhang (2009) assume that the female-male wage (productivity) differential is the same for skilled and unskilled groups, which implies a constant gender wage (productivity) ratio as conjectured in our study. Thus, the impact of this data limitation on the estimation of the gender wage and productivity ratios could be minimal.
} 
of female labor, $L_{t}$ is the total labor, and $K_{t}$ is the total fixed asset. The vectors $X_{t}$ and $Z_{t}$ contain other firm characteristics, including: (1) ownership, which is five indicators for state owned enterprises (SOEs), collectively owned enterprises (COEs), private enterprises, Hong Kong-Macao-Taiwan invested enterprises (HMTs), and foreign invested enterprises (FIEs), with the baseline category of domestic joint ventures (DJVs); (2) firm size, measured by the logarithm of total sales; (3) capital-labor ratio in the wage equation, defined as fixed assets divided by the size of employment; (4) market share, measured by the share of sales of the same 4-digit industrial sales, and (5) province and industry dummies to capture the regional and industrial effects, respectively.

The selection of these control variables is in line with the existent empirical studies. Furthermore, certain unobserved factors that are subsumed within the two error terms, $u_{t}$ and $v_{t}$, may drive wages and productivity simultaneously. To recognize the potential correlation between these error terms, we assume that the two error terms have a bivariate distribution with a correlation coefficient of $\epsilon$.

The above structural framework of the joint determination of wage and productivity holds a major advantage over the conventional residual wage gap analysis: it attenuates the potential omitted-variable bias (Altonji and Blank, 1999), as workers' unobserved productivity characteristics tend to affect both wage and productivity in a similar manner. It is of particular interest to estimate $\phi_{t}$, the wage ratio of female to male employees, and $\rho_{t}$, the marginal productivity of female to male workers. If $\phi_{t}<1$, then it implies a lower wage for female workers than for comparable male workers. An estimate of $\rho_{t}<1$ would indicate that women are less productive than men in the labor market.

Therefore, another advantage of our method is that it provides a statistically sound testing procedure for the evaluation of gender wage discrimination. Specifically, the null hypothesis of no gender wage discrimination in year $t$ can be formulated as $\phi_{t}=\rho_{t}$, meaning that the wage gap merely reflects the gender productivity difference between female and male workers. Conversely, a rejection of the null hypothesis produces statistical evidence for gender wage discrimination (i.e. $\phi_{t}<\rho_{t}$ ) or evidence supporting a wage subsidy for female employees (i.e. $\phi_{t}>\rho_{t}$ ).

The system of wage and productivity equations is estimated jointly with nonlinear least squares, which facilitates a direct test of the existence of gender wage discrimination (i.e. $\phi_{t}=\rho_{t}$ ) and changes in the trends of gender wage and pro- 
ductivity ratios (e.g. $\phi_{t}=c \forall t$ where $c$ is a constant, and $\rho_{t}<\phi_{t+1}$ ). Our primary focus is to statistically examine the relationship between the gender wage ratio, $\phi_{t}$, and the marginal productivity ratio, $\rho_{t}$, across the four-year period from 2004 to 2007. The estimates of $\phi_{t}$ and $\rho_{t}$ and the related test results are reported in the next section. In addition, we estimate a model in which $\phi_{t}$ and $\rho_{t}$ are assumed to have constant growth rates, $g_{\phi}$ and $g_{\rho}$, respectively. Consequently, $\phi_{t+n}$ would be equal to $\phi_{t}\left(1+g_{\phi}\right)^{n}$, and $\rho_{t+n}$ would be equal to $\rho_{t}\left(1+g_{\rho}\right)^{n}$ where the 2004 gender wage and productivity rates are used as baselines, respectively.

Compared with most recent existing literature (e.g. Hellerstein and Neumark, 1999; and Dong and Zhang, 2009) that relies on cross-sectional or survey data to identify gender discrimination, utilizing the panel data set enables us to gauge the difference between the wage and productivity gaps at a particular time, and more importantly, to examine the time trend in the wage-productivity differential. As a result, we are able to investigate the impact of FDI and exports on gender discrimination and its evolution over time.

\section{Data and Descriptive Analysis}

This paper focuses on the manufacturing sector, which has driven China's economic growth and has been the major recipient of foreign direct investment inflows. The data is from the National Bureau of Statistics Enterprise Data published by the National Bureau of Statistics of China (NBSC). The information is obtained from the annual reports of almost all state enterprises and the large and medium-sized non-state enterprises with sales above 5 million RMB. ${ }^{6}$

The analyses in this paper are based on the unbalanced firm-level panel for the 2004 to 2007 period. The annual report details firms' financial activities, including sales, employment, and assets, as well as certain non-financial information, such as

\footnotetext{
${ }^{6}$ The basic statistics of the aggregate manufacturing sector are summarized in the China Statistical Yearbooks, and the statistics of the two-digit manufacturing industries are summarized in the China Industry Economy Statistical Yearbooks based on this dataset. Dividing the total value added by the industrial GDP reported in China's Statistical Yearbook indicates that the survey accounts for 94 percent of total industrial output. Brandt et al. (2012), in their analysis of firm productivity growth in China, showed that firms with sales below 5 million RMB account for only a small fraction of economic activity. For example, in 2004, these firms produced only 9.9 percent of total output and generated 2.5 percent of total exports.
} 
entry date, district code, industry code, and the main products of the enterprises. Previous literature used small cross-sectional datasets to study the effects of globalization on wages and employment in China. The use of this comprehensive data set not only enables us to delve deeper into the effects of international exposure on gender differentials, but also facilitates a generalization of our results to other developing countries.

Table 1 presents the summary statistics by firm category. While the distribution of firms across ownership categories is non-uniform, the survey offers a sizable representation for each group. Of the 60,000 firms covered in our sample, approximately one-quarter are owned by domestic investors. The number of firms that are solely owned by the state is relatively small, representing 9 percent of the sample. Private ownership is more prevalent, covering about 30 percent of the firms. About 45 percent of the firms are exporters, 15 percent are foreign-invested, and 17 percent are HMT-invested enterprises.

The variables in this paper are constructed as follows. Wages are computed as the total wage bill of a firm divided by its number of employees and defined in thousands of RMB, deflated by the consumer price index with 2004 as the base year. Output is measured as the value-added, while capital is defined as the fixed assets of the firm. Because of the time variation in the survey, we deflate outputs and capital by the GDP deflator with 2004 as the base year. The capital-labor ratio is then defined as capital divided by firm employment. Firm age indicates the age of the firm in 2007, and is computed based on the firm's year of establishment. Firm size is defined as the total sales of the firm. Market share is the share of major products in domestic markets as in Dong and Zhang (2009), and it is computed as the ratio of a firm's sales to the total 1-digit industry sales. The export intensity of the firm is defined as the percentage of exports in sales revenue.

In terms of wages, there is considerable variation both within and across ownership categories. FIE's wages are approximately 26 percent larger than domesticallyowned enterprises, but only 4 percent more than SOE's, on average. The average output among FIE's is also larger, indicating that labor may be more productive in this category. While the number of SOE's in our sample is relatively small, their market share is the highest, indicating that these firms tend to be much larger than both domestic and foreign-invested private firms. This can be seen in the number of employees, as foreign invested firms hires 720 workers while state owned 
Table 1: Summary Statistics

\begin{tabular}{|c|c|c|c|c|c|c|c|c|c|c|c|c|c|}
\hline & 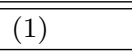 & 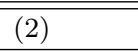 & (3) & 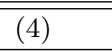 & 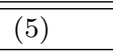 & $\overline{~(6)}$ & 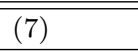 & 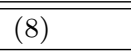 & (9) & (10) & 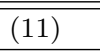 & (12) & (13) \\
\hline & All firms & Domestic & $\mathrm{SOE}$ & $\mathrm{COE}$ & Private & HMT & $\begin{array}{l}\text { Non- Ex- } \\
\text { porter }\end{array}$ & Exporter & $\begin{array}{l}\text { Exporter } \\
1^{s t} \text { Tercile }\end{array}$ & $\begin{array}{l}\text { Exporter } \\
3^{\text {rd }} \text { Tercile } \\
\end{array}$ & FIE & $\begin{array}{l}\text { FIE } 1^{\text {st }} \\
\text { Tercile }\end{array}$ & $\begin{array}{l}\text { FIE } 3^{\text {rd }} \\
\text { Tercile }\end{array}$ \\
\hline$N$ & 245,499 & 60,026 & 21,817 & 10,029 & 74,688 & 41,480 & 133,924 & 111,575 & 37,192 & 37,192 & 37,464 & 12,488 & 12,488 \\
\hline $\ln (W)$ & $\begin{array}{l}2.759 \\
{[0.583]}\end{array}$ & $\begin{array}{l}2.737 \\
{[0.581]}\end{array}$ & $\begin{array}{l}2.959 \\
{[0.682]}\end{array}$ & $\begin{array}{l}2.526 \\
{[0.544]}\end{array}$ & $\begin{array}{l}2.602 \\
{[0.490]}\end{array}$ & $\begin{array}{l}2.806 \\
{[0.529]}\end{array}$ & $\begin{array}{l}2.709 \\
{[0.601]}\end{array}$ & $\begin{array}{l}2.818 \\
{[0.554]}\end{array}$ & $\begin{array}{l}2.925 \\
{[0.619]}\end{array}$ & $\begin{array}{l}2.718 \\
{[0.487]}\end{array}$ & $\begin{array}{l}2.999 \\
{[0.629]}\end{array}$ & $\begin{array}{l}2.871 \\
{[0.622]}\end{array}$ & $\begin{array}{l}3.056 \\
{[0.600]}\end{array}$ \\
\hline $\ln (Q)$ & $\begin{array}{l}9.861 \\
{[1.410]}\end{array}$ & $\begin{array}{l}10.10 \\
{[1.471]}\end{array}$ & $\begin{array}{l}10.17 \\
{[1.726]}\end{array}$ & $\begin{array}{l}9.567 \\
{[1.330]}\end{array}$ & $\begin{array}{l}9.519 \\
{[1.165]}\end{array}$ & $\begin{array}{l}9.726 \\
{[1.316]}\end{array}$ & $\begin{array}{l}9.798 \\
{[1.379]}\end{array}$ & $\begin{array}{l}9.938 \\
{[1.442]}\end{array}$ & $\begin{array}{l}10.52 \\
{[1.554]}\end{array}$ & $\begin{array}{l}9.452 \\
{[1.234]}\end{array}$ & $\begin{array}{l}10.21 \\
{[1.477]}\end{array}$ & $\begin{array}{l}10.10 \\
{[1.474]}\end{array}$ & $\begin{array}{l}10.21 \\
{[1.451]}\end{array}$ \\
\hline $\ln (A g e)$ & $\begin{array}{l}2.632 \\
{[0.579]}\end{array}$ & $\begin{array}{l}2.697 \\
{[0.640]}\end{array}$ & $\begin{array}{l}3.420 \\
{[0.642]}\end{array}$ & $\begin{array}{l}3.018 \\
{[0.479]}\end{array}$ & $\begin{array}{l}2.459 \\
{[0.464]}\end{array}$ & $\begin{array}{l}2.503 \\
{[0.377]}\end{array}$ & $\begin{array}{l}2.670 \\
{[0.632]}\end{array}$ & $\begin{array}{l}2.586 \\
{[0.503]}\end{array}$ & $\begin{array}{l}2.734 \\
{[0.618]}\end{array}$ & $\begin{array}{l}2.492 \\
{[0.385]}\end{array}$ & $\begin{array}{l}2.454 \\
{[0.366]}\end{array}$ & $\begin{array}{l}2.462 \\
{[0.388]}\end{array}$ & $\begin{array}{l}2.449 \\
{[0.341]}\end{array}$ \\
\hline$K / L$ & $\begin{array}{l}3.794 \\
{[1.381]}\end{array}$ & $\begin{array}{l}4.085 \\
{[1.323]}\end{array}$ & $\begin{array}{l}4.684 \\
{[1.212]}\end{array}$ & $\begin{array}{l}3.288 \\
{[1.371]}\end{array}$ & $\begin{array}{l}3.477 \\
{[1.231]}\end{array}$ & $\begin{array}{l}3.443 \\
{[1.413]}\end{array}$ & $\begin{array}{l}3.974 \\
{[1.366]}\end{array}$ & $\begin{array}{l}3.579 \\
{[1.369]}\end{array}$ & $\begin{array}{l}4.222 \\
{[1.229]}\end{array}$ & $\begin{array}{l}2.939 \\
{[1.297]}\end{array}$ & $\begin{array}{l}3.967 \\
{[1.443]}\end{array}$ & $\begin{array}{l}3.851 \\
{[1.463]}\end{array}$ & $\begin{array}{l}3.997 \\
{[1.400]}\end{array}$ \\
\hline $\ln ($ Size $)$ & $\begin{array}{l}11.13 \\
{[1.364]}\end{array}$ & $\begin{array}{l}11.33 \\
{[1.427]}\end{array}$ & $\begin{array}{l}11.28 \\
{[1.732]}\end{array}$ & $\begin{array}{l}10.77 \\
{[1.275]}\end{array}$ & $\begin{array}{l}10.81 \\
{[1.116]}\end{array}$ & $\begin{array}{l}11.07 \\
{[1.258]}\end{array}$ & $\begin{array}{l}11.01 \\
{[1.316]}\end{array}$ & $\begin{array}{l}11.29 \\
{[1.405]}\end{array}$ & $\begin{array}{l}11.83 \\
{[1.510]}\end{array}$ & $\begin{array}{l}10.82 \\
{[1.231]}\end{array}$ & $\begin{array}{l}11.54 \\
{[1.424]}\end{array}$ & $\begin{array}{l}11.40 \\
{[1.417]}\end{array}$ & $\begin{array}{l}11.56 \\
{[1.394]}\end{array}$ \\
\hline Market share $\left(X 10^{4}\right)$ & $\begin{array}{l}0.220 \\
{[2.821]}\end{array}$ & $\begin{array}{l}0.244 \\
{[2.047]}\end{array}$ & $\begin{array}{l}0.653 \\
{[7.508]}\end{array}$ & $\begin{array}{l}0.093 \\
{[0.680]}\end{array}$ & $\begin{array}{l}0.057 \\
{[0.197]}\end{array}$ & $\begin{array}{l}0.158 \\
{[1.231]}\end{array}$ & $\begin{array}{l}0.186 \\
{[3.075]}\end{array}$ & $\begin{array}{l}0.261 \\
{[2.481]}\end{array}$ & $\begin{array}{l}0.407 \\
{[2.971]}\end{array}$ & $\begin{array}{l}0.180 \\
{[2.323]}\end{array}$ & $\begin{array}{l}0.355 \\
{[3.246]}\end{array}$ & $\begin{array}{l}0.276 \\
{[1.771]}\end{array}$ & $\begin{array}{l}0.387 \\
{[3.996]}\end{array}$ \\
\hline Export Intensity & $\begin{array}{l}0.278 \\
{[0.399]}\end{array}$ & $\begin{array}{l}0.121 \\
{[0.270]}\end{array}$ & $\begin{array}{l}0.035 \\
{[0.129]}\end{array}$ & $\begin{array}{l}0.107 \\
{[0.278]}\end{array}$ & $\begin{array}{l}0.212 \\
{[0.361]}\end{array}$ & $\begin{array}{l}0.576 \\
{[0.435]}\end{array}$ & $\begin{array}{l}0 \\
-\end{array}$ & $\begin{array}{l}0.612 \\
{[0.383]}\end{array}$ & $\begin{array}{l}0.146 \\
{[0.141]}\end{array}$ & $\begin{array}{l}0.990 \\
{[0.028]}\end{array}$ & $\begin{array}{l}0.520 \\
{[0.426]}\end{array}$ & $\begin{array}{l}0.436 \\
{[0.426]}\end{array}$ & $\begin{array}{l}0.601 \\
{[0.413]}\end{array}$ \\
\hline Employment & $\begin{array}{l}682.7 \\
{[2360]}\end{array}$ & $\begin{array}{l}782.9 \\
{[2743]}\end{array}$ & $\begin{array}{l}1520 \\
{[5609]}\end{array}$ & $\begin{array}{l}544.9 \\
{[1112]}\end{array}$ & $\begin{array}{l}379.1 \\
{[448.6]}\end{array}$ & $\begin{array}{l}643.5 \\
{[1084]}\end{array}$ & $\begin{array}{l}542.0 \\
{[1755]}\end{array}$ & $\begin{array}{l}851.6 \\
{[2916]}\end{array}$ & $\begin{array}{l}1190 \\
{[4343]}\end{array}$ & $\begin{array}{l}695.7 \\
{[1686]}\end{array}$ & $\begin{array}{l}720.2 \\
{[1862]}\end{array}$ & $\begin{array}{l}642.9 \\
{[1203]}\end{array}$ & $\begin{array}{l}758.7 \\
{[1409]}\end{array}$ \\
\hline Female Share & $\begin{array}{l}0.466 \\
{[0.188]}\end{array}$ & $\begin{array}{l}0.419 \\
{[0.176]}\end{array}$ & $\begin{array}{l}0.352 \\
{[0.132]}\end{array}$ & $\begin{array}{l}0.463 \\
{[0.180]}\end{array}$ & $\begin{array}{l}0.481 \\
{[0.179]}\end{array}$ & $\begin{array}{l}0.526 \\
{[0.190]}\end{array}$ & $\begin{array}{l}0.430 \\
{[0.173]}\end{array}$ & $\begin{array}{l}0.510 \\
{[0.196]}\end{array}$ & $\begin{array}{l}0.428 \\
{[0.184]}\end{array}$ & $\begin{array}{l}0.570 \\
{[0.185]}\end{array}$ & $\begin{array}{l}0.514 \\
{[0.203]}\end{array}$ & $\begin{array}{l}0.497 \\
{[0.202]}\end{array}$ & $\begin{array}{l}0.543 \\
{[0.201]}\end{array}$ \\
\hline
\end{tabular}

Notes: Standard deviations of variables are presented in brackets. The column names represent the ownership type of the firms, with abbreviations defined as follows: SOE (state-owned enterprises), COE (collectively-owned enterprises), HMT (Hong Kong-Macao-Taiwan invested enterprises) and FIE (foreign invested enterprises). FIEs are defined as firms with a foreign capital share of greater than or equal to 10 percent. Wages are the total wage bill divided by the number of employees, and defined in thousands of RMB. Output is measured as the value-added. The capital-labor ratio is defined as the fixed assets of the firm divided by its employment. Firm age indicates the age of the firm in 2007 , and firm size is the total sales of the firm. Market share is the ratio of a firm's sales to the total 1-digit industry sales. The export intensity of the firm is defined as the percentage of exports in sales revenue. All of the relevant variables are deflated with 2004 as the base year. The $1^{\text {st }}\left(3^{\text {rd }}\right)$ tercile of exporters contains one third of exporters with the lowest (highest) export shares. The $1^{\text {st }}\left(3^{\text {rd }}\right)$ tercile of FIEs contains one-third of FIEs with the lowest (highest) foreign capital ratios. 
firms hires about 1520 workers, on average.

In a labor-abundant country, exporter firms are expected to specialize in laborintensive products. This can be seen in columns (9) and (10) of Table 1, where capital intensity decreases substantially with the export intensity of the firm. The lowest capital-labor ratio is observed for exporters with the highest export share ( $3^{\text {rd }}$ tercile). Wages and firm size, both in terms of value-added and sales tend to be lower for the firms with high export intensity. Compared to the $1^{\text {st }}$ tercile with respect to export intensity, we see that the average output is about 11 percent lower, and the average employment is about 41 percent lower in the $3^{\text {rd }}$ tercile, even though these firms are more labor intensive. This indicates that a Melitztype mechanism may be in place where exporter firms tend to be relatively more productive.

FIEs, on the other hand, are more capital-intensive than exporter firms. This is consistent with their lower export intensity and higher market share, which indicate that they are primarily targeting the domestic market, where their relative advantage is likely to be in the efficient use of capital or skilled labor. While FIEs are less capital intensive than domestically owned firms, on average, they pay higher wages, employ less workers, export more, and have more market power in their respective industries.

The relationship between export intensity and female employment can be seen clearly in Figure 1, where the nonparametric local polynomial regressions of the share of female employment conditional on export intensity are presented. The share of female workforce increases linearly with export intensity in all years. The slope of the line decreases in each year, indicating that this relationship has weakened over time. For example, in 2007, a firm with 6 percent export intensity had a female employment ratio approximately equal to 43 percent and a firm with 86 percent export intensity had a female employment ratio around 52 percent. On the other hand, in 2004, the average female ratio among firms with 86 percent export intensity was at a higher level around 58 percent. ${ }^{7}$ The relationship between

\footnotetext{
${ }^{7}$ All local polynomial regressions are of degree one with a bandwidth of 0.2. Although the confidence intervals are not presented to simplify the figures, they are narrow enough that the differences across years are statistically significant for both export intensity and foreign capital shares. The relationship between export intensity and the female share is found to be linear in all specifications.
} 
foreign investment and the female ratio is exponential and does not appear to change significantly over time. In all years, the female ratio increases with the ratio of foreign capital, and the rate also increases as we move right on the foreign capital spectrum. Foreign firms tend to have a relatively lower share of female workers than exporter firms, with rates varying between 10 percent and 35 percent.

In light of these characteristic differences between domestic firms, exporters, and foreign invested firms, it is clear that the empirical question of whether or not globalization exacerbates or mitigates the gender wage gap is not straightforward. The female ratio is higher among exporters and this ratio increases with export intensity. Given that labor intensity also increases in the same direction, it is plausible that female labor is hired as a substitute, and not a complement, for capital. In other words, the higher female ratio does not imply an increase in skilled labor that work along with knowledge-intensive technology. Rather, it is more consistent with an increase in unskilled labor that replaces technology (for example, the hand-stitching of apparel rather than the use of sewing machines). A similar trend is apparent in FIEs, where both labor intensity and the female ratio increase with the percentage of foreign investment.

The process of globalization may increase job opportunities for women, inducing them to participate in the labor market, which may improve their economic status. It may also lead to occupational segregation, where women are trapped in low-paying, low-skilled jobs. This paper focuses on the question of whether females are being paid their marginal product relative to male workers, and whether the exporting firms or foreign invested firms have structural differences or different trends in terms of their gender wage-productivity differentials. More specifically, we estimate the wage and productivity levels of female workers relative to male workers for each ownership category, and provide formal tests of the equality of these ratios. In the next section, we present and discuss our main findings.

\section{Results}

The analyses in this paper are carried out by estimating a series of simultaneous equation systems using nonlinear least squares. Using this methodology, we jointly determine wages and productivity levels. We first present the results with data that are pooled across years, and therefore, the wage and productivity differentials 
Figure 1: Female Share of Employment
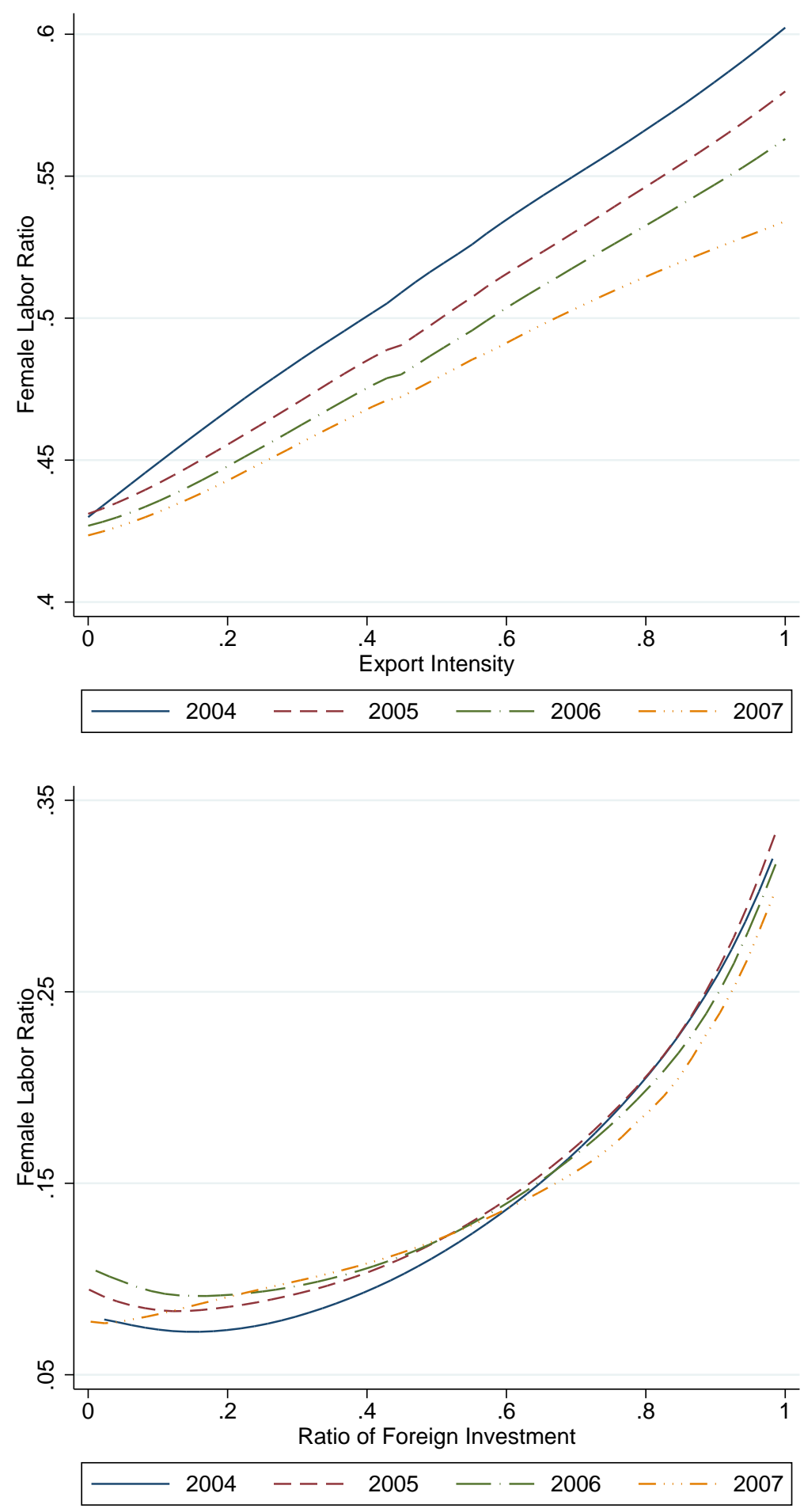
are assumed to be constant over time. The first row of Table 2 presents the gender wage ratio, $\phi$, where an estimate lower than unity indicates that female wages are lower than male wages, on average. The enterprises are distinguished by ownership and trade activity in order to investigate the structural differences in terms of the gender wage differentials. For each category, the $p$ values for the tests of no gender wage differentials, with the null hypothesis of $\phi=1$, are presented in the second row.

The results suggest that, on average, the female workforce is paid approximately 82 percent of the wage of the male workforce, and the differential is statistically significant (column 1). In no enterprise category do we find that the gender wage ratio is equal to one, or that the difference is statistically insignificant. Keeping in mind that the female work force may be less productive, possess less human capital, or be disproportionately represented in low-skill occupations, these ratios indicate a raw wage gap rather than gender discrimination by employers.

As expected, state-owned enterprises have the highest gender wage ratio, $\phi$, where females are paid approximately 90 percent of the wages of male workers. A relatively high gender wage ratio and female employment share indicate that female workers, on average, are employed in occupations that have similar wage rates as the occupations of male workers. The gender wage ratio is lowest among FIEs, and increases with the share of foreign investment. Given that these enterprises are relatively more capital intensive, and employ a disproportionately high number of women, these results are consistent with the relatively high number of skilled female workers. The gender ratio is lower among exporters relative to nonexporters, and decreases with the export-orientation of the firm, which is again consistent with a disproportionate amount of unskilled labor.

Moving to the productivity ratio estimates, $\rho$, women are more productive than men in domestically-owned enterprises, private enterprises, and non-exporters, where they are still paid less than male workers, on average. The null hypothesis of no wage-productivity differentials, $\phi=\rho$, is therefore rejected against $\phi<\rho$ at the 1 percent level, indicating that the relative wage of women is less than their relative marginal product, with the exception of non-exporters where the hypothesis is rejected only at the 10 percent level. On the other hand, women are less productive than men in COEs, HMTs, and exporting firms. The lower productivity of female workers can partially explain the wage gap in these categories. 
Table 2: Joint Estimation of the Wage Equation and the Production Function - Pooled Data

\begin{tabular}{|c|c|c|c|c|c|c|c|c|c|c|c|c|c|}
\hline & $(1)$ & $(2)$ & $(3)$ & $(4)$ & $(5)$ & $(6)$ & $(7)$ & $(8)$ & $(9)$ & $(10)$ & $(11)$ & $(12)$ & $(13)$ \\
\hline & All firms & Domestic & SOE & $\mathrm{COE}$ & Private & HMT & $\begin{array}{l}\text { Non- Ex- } \\
\text { porter }\end{array}$ & Exporter & $\begin{array}{l}\text { Exporter } \\
1^{s t} \text { Tercile }\end{array}$ & $\begin{array}{l}\text { Exporter } \\
3^{\text {rd }} \text { Tercile }\end{array}$ & FIE & $\begin{array}{l}\text { FIE } 1^{\text {st }} \\
\text { Tercile }\end{array}$ & $\begin{array}{l}\text { FIE } 3^{r d} \\
\text { Tercile }\end{array}$ \\
\hline Gender wage ratio $\phi$ & $\begin{array}{l}0.818^{* * *} \\
(171.6)\end{array}$ & $\begin{array}{l}0.811^{* * *} \\
(77.20)\end{array}$ & $\begin{array}{l}0.905^{* * *} \\
(33.65)\end{array}$ & $\begin{array}{l}0.870^{* * *} \\
(34.14)\end{array}$ & $\begin{array}{l}0.861^{* * *} \\
(103.5)\end{array}$ & $\begin{array}{l}0.769^{* * *} \\
(82.09)\end{array}$ & $\begin{array}{l}0.900^{* * *} \\
(111.3)\end{array}$ & $\begin{array}{l}0.778^{* * *} \\
(121.9)\end{array}$ & $\begin{array}{l}0.860^{* * *} \\
(80.79)\end{array}$ & $\begin{array}{l}0.770^{* * *} \\
(88.26)\end{array}$ & $\begin{array}{l}0.688^{* * *} \\
(63.66)\end{array}$ & $\begin{array}{l}0.649^{* * *} \\
(38.48)\end{array}$ & $\begin{array}{l}0.689^{* * *} \\
(49.30)\end{array}$ \\
\hline Test: $\phi=1$ & 0.000 & 0.000 & 0.000 & 0.000 & 0.000 & 0.000 & 0.000 & 0.000 & 0.000 & 0.000 & 0.000 & 0.000 & 0.000 \\
\hline Gender productivity ratio $\rho$ & $\begin{array}{l}0.918^{* * *} \\
(20.65)\end{array}$ & $\begin{array}{l}1.540^{* * *} \\
(6.73)\end{array}$ & $\begin{array}{l}0.110 \\
(1.04)\end{array}$ & $\begin{array}{l}0.597^{* * *} \\
(3.59)\end{array}$ & $\begin{array}{l}1.064^{* * *} \\
(10.01)\end{array}$ & $\begin{array}{l}0.538^{* * *} \\
(16.84)\end{array}$ & $\begin{array}{l}1.122^{* * *} \\
(9.39)\end{array}$ & $\begin{array}{l}0.768^{* * *} \\
(18.13)\end{array}$ & $\begin{array}{l}0.600^{* * *} \\
(13.49)\end{array}$ & $\begin{array}{l}0.746^{* * *} \\
(21.92)\end{array}$ & $\begin{array}{l}0.390^{* * *} \\
(10.56)\end{array}$ & $\begin{array}{l}0.331^{* * *} \\
(4.05)\end{array}$ & $\begin{array}{l}0.418^{* * *} \\
(9.81)\end{array}$ \\
\hline Test: $\rho=1$ & 0.066 & 0.0183 & 0.000 & 0.015 & 0.548 & 0.000 & 0.308 & 0.000 & 0.000 & 0.000 & 0.025 & 0.000 & 0.000 \\
\hline Test: $\phi=\rho$ & 0.023 & 0.001 & 0.000 & 0.099 & 0.057 & 0.000 & 0.062 & 0.720 & 0.111 & 0.875 & 0.000 & 0.000 & 0.000 \\
\hline$N$ & 245,499 & 60,024 & 21,817 & 10,029 & 74,688 & 41,477 & 133,924 & 111,575 & 37,192 & 37,192 & 37,464 & 12,488 & 12,488 \\
\hline$R^{2}$ (Wage Equation) & 0.494 & 0.545 & 0.596 & 0.290 & 0.269 & 0.340 & 0.515 & 0.483 & 0.548 & 0.333 & 0.430 & 0.558 & 0.346 \\
\hline$R^{2}$ (Productivity Equation) & 0.938 & 0.944 & 0.953 & 0.916 & 0.880 & 0.885 & 0.931 & 0.943 & 0.950 & 0.899 & 0.903 & 0.920 & 0.879 \\
\hline Correlation of error terms $\epsilon$ & 0.152 & 0.0972 & 0.146 & 0.115 & 0.135 & 0.169 & 0.123 & 0.169 & 0.119 & 0.200 & 0.186 & 0.188 & 0.171 \\
\hline
\end{tabular}

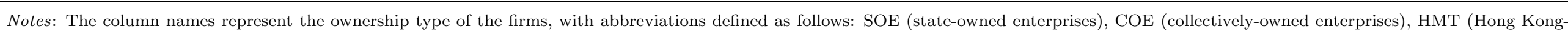

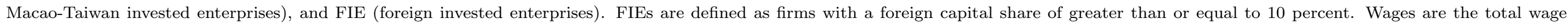

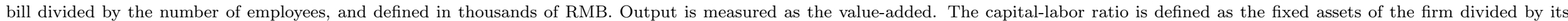

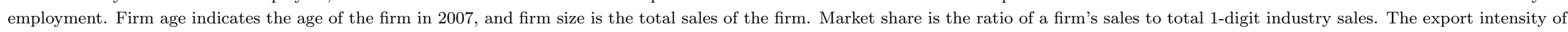

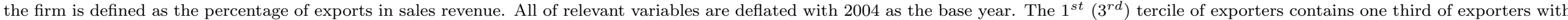

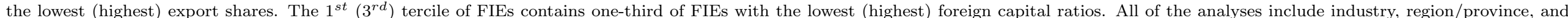
year fixed effects. ${ }^{* * *} \mathrm{p}<0.01,{ }^{* *} \mathrm{p}<0.05,{ }^{*} \mathrm{p}<0.1$. 
We then test whether these ratios are significantly different from one another. At the 5 percent level, we are not able to reject the null hypothesis of no wageproductivity differentials for COEs, private firms, and exporters.

Interestingly, among exporting firms, we find that the relative wage of women is statistically equivalent to their relative productivity, also indicating nondiscrimination. This is consistent with Becker's hypothesis that competition should reduce discrimination as it is costly to the firm (Becker, 1957), and also aligns with evidence in the empirical literature which found that globalization tends to reduce discrimination among exporters by increasing competition faced by the firm (Black and Brainerd, 2004; Mennon and Rodgers, 2008). FIEs, on the other hand, show different characteristics. While the productivity and wage differentials are both lowest, in relative terms, these firms actually pay female workers more than their relative marginal product. As a result, we find that women are paid a premium in these enterprises $(\phi>\rho)$.

In short, the results using pooled data suggest that gender wage-productivity differentials are not significant among exporters, positive among FIEs, and negative among domestically owned, private, and non-exporter firms. However, it is important to analyze how these differentials evolve over time in order to understand whether it is the relative improvement of wages or productivity levels that drive the comparatively less discrimination found among globalized firms. Table 3 presents the estimates for firm-level growth rates. These results suggest that relative productivity levels of female workers grew much faster than their relative wages (column 1). This was especially true for domestically owned firms, COEs, private firms and non-exporters.

Female workers employed in exporting firms and SOEs, on the other hand, showed similar growth rates in their relative wages and productivity levels. Only among those firms with small export shares (within the $1^{\text {st }}$ tercile) do we find weak evidence of faster growth in productivity levels. Similarly, we find only weak evidence of slightly faster productivity growth among FIEs, while this evidence becomes significant among firms that have relatively high shares of foreign investment, which is consistent with the lower levels of wage-productivity differentials presented in Table 2. The results suggest that differential wage-productivity growth was observed among non-exporters and privately-owned domestic firms, but not as much among exporters and foreign-owned firms. 
Table 3: Joint Estimation of the Wage Equation and the Production Function - Growth Rates

\begin{tabular}{|c|c|c|c|c|c|c|c|c|c|c|c|c|c|}
\hline & (1) & $(2)$ & (3) & $(4)$ & $(5)$ & (6) & $\overline{(7)}$ & $(8)$ & (9) & $\overline{(10)}$ & (11) & 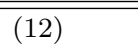 & 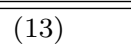 \\
\hline & All firms & Domestic & SOE & $\mathrm{COE}$ & Private & HMT & $\begin{array}{l}\text { Non- Ex- } \\
\text { porter }\end{array}$ & Exporter & $\begin{array}{l}\text { Exporter } \\
1^{s t} \text { Tercile }\end{array}$ & $\begin{array}{l}\text { Exporter } \\
3^{\text {rd }} \text { Tercile }\end{array}$ & FIE & $\begin{array}{l}\text { FIE } 1^{\text {st }} \\
\text { Tercile }\end{array}$ & $\begin{array}{l}\text { FIE } 3^{\text {rd }} \\
\text { Tercile }\end{array}$ \\
\hline Wage Growth $g_{\phi}$ & $\begin{array}{l}0.258^{* * *} \\
(112.9)\end{array}$ & $\begin{array}{l}0.245^{* * *} \\
(47.28)\end{array}$ & $\begin{array}{l}0.298^{* * *} \\
(25.59)\end{array}$ & $\begin{array}{l}0.247^{* * *} \\
(23.01)\end{array}$ & $\begin{array}{l}0.265^{* * *} \\
(71.58)\end{array}$ & $\begin{array}{l}0.295^{* * *} \\
(64.76)\end{array}$ & $\begin{array}{l}0.258^{* * *} \\
(69.56)\end{array}$ & $\begin{array}{l}0.258^{* * *} \\
(85.70)\end{array}$ & $\begin{array}{l}0.264^{* * *} \\
(53.42)\end{array}$ & $\begin{array}{l}0.257^{* * *} \\
(65.27)\end{array}$ & $\begin{array}{l}0.222^{* * *} \\
(43.38)\end{array}$ & $\begin{array}{l}0.283^{* * *} \\
(32.23)\end{array}$ & $\begin{array}{l}0.218^{* * *} \\
(30.57)\end{array}$ \\
\hline Prod.Growth $g_{\rho}$ & $\begin{array}{l}0.555^{* * *} \\
(23.15)\end{array}$ & $\begin{array}{l}0.493^{* * *} \\
(7.84)\end{array}$ & $\begin{array}{l}0.287^{* * *} \\
(5.37)\end{array}$ & $\begin{array}{l}0.774^{* * *} \\
(4.54)\end{array}$ & $\begin{array}{l}0.544^{* * *} \\
(14.43)\end{array}$ & $\begin{array}{l}0.543^{* * *} \\
(16.43)\end{array}$ & $\begin{array}{l}0.677^{* * *} \\
(10.49)\end{array}$ & $\begin{array}{l}0.286^{* * *} \\
(20.21)\end{array}$ & $\begin{array}{l}0.328^{* * *} \\
(12.64)\end{array}$ & $\begin{array}{l}0.279^{* * *} \\
(19.98)\end{array}$ & $\begin{array}{l}0.286^{* * *} \\
(7.74)\end{array}$ & $\begin{array}{l}0.337^{* * *} \\
(7.38)\end{array}$ & $\begin{array}{l}0.234^{* * *} \\
(5.93)\end{array}$ \\
\hline Test: $g_{\phi}=g_{\rho}$ & 0.000 & 0.000 & 0.242 & 0.002 & 0.000 & 0.000 & 0.000 & 0.127 & 0.081 & 0.173 & 0.078 & 0.055 & 0.242 \\
\hline$N$ & 245,499 & 60,024 & 21,817 & 10,029 & 74,688 & 41,477 & 133,924 & 111,575 & 37,192 & 37,192 & 37,464 & 12,488 & 12,488 \\
\hline$R^{2}$ (Wage Equation) & 0.526 & 0.567 & 0.615 & 0.333 & 0.331 & 0.416 & 0.535 & 0.514 & 0.572 & 0.414 & 0.462 & 0.466 & 0.407 \\
\hline$R^{2}$ (Productivity Equation) & 0.938 & 0.944 & 0.953 & 0.916 & 0.880 & 0.885 & 0.931 & 0.943 & 0.950 & 0.899 & 0.903 & 0.920 & 0.879 \\
\hline Correlation of error terms $\epsilon$ & 0.142 & 0.0911 & 0.141 & 0.104 & 0.122 & 0.145 & 0.114 & 0.150 & 0.112 & 0.172 & 0.181 & 0.137 & 0.157 \\
\hline
\end{tabular}

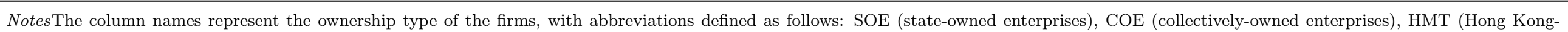

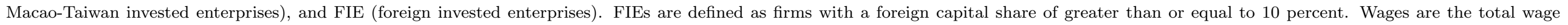

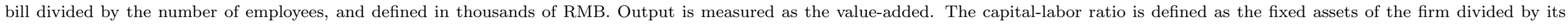

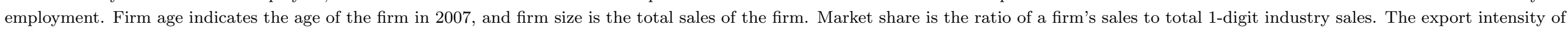

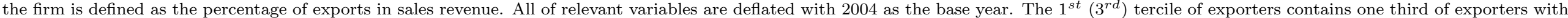

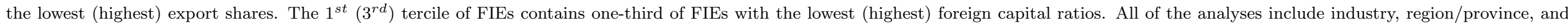
year fixed effects. $* * * \mathrm{p}<0.01, * * \mathrm{p}<0.05, * \mathrm{p}<0.1$. 
Overall, we find that exporter firms do a better job matching relative wages to relative productivity levels of workers as they tend to operate with lower profit margins, and thus cannot afford to be involved in inefficient practices such as discrimination. However, among non-exporters, there is a large gap between the relative productivity and wage growth of women. During this time period, their relative productivity grew by 67.7 percent, while their wage rate grew by only 25.8 percent, suggesting that the wage-productivity differentials are more prevalent among these enterprises.

It is possible that both the wage and productivity ratios changed over time for each ownership category, violating the assumption of constant coefficients. One method to incorporate time variation into the wage and productivity ratios is to interact the coefficients with time dummies, and focus on the coefficients of these interaction variables to understand the differential changes in these ratios. This method, however, is not appropriate in cases where the time variations in the coefficients are nonlinear, and it is especially restrictive because the system of equations in this paper are estimated with nonlinear least squares. In addition, this method increases the number of coefficients to be estimated, reducing consistency and increasing computational cost. ${ }^{8}$

Instead, we estimate the nonlinear system of equations with the time-varying parameters $\phi_{t}$ and $\rho_{t}$. For each $t$, we test whether there are significant gender wage or productivity gaps, and whether these ratios are statistically equivalent to each other. This approach allows us to analyze the evolution of wage discrimination outcomes for each firm type, and identify the source of their variation. We can assess, for example, whether an observed reduction in wage discrimination stems from increased an gender wage ratio, a reduced productivity ratio, or from both ratios moving in the same direction, but at different rates. The results of this estimation procedure are presented separately for each year in Table 4.

The results in Column (1) suggest that, when all firms are considered within a single framework, the productivity ratios of female workers are significantly greater than their wage ratios in 2004 and 2005. However, the difference is insignificant for 2006 and 2007, not because the relative female wages improved, but rather because their relative productivity declined. Female workers were significantly more productive than male workers in the earlier years, while their productivity

\footnotetext{
${ }^{8}$ The estimation of each nonlinear system of equations takes approximately 10 hours to run.
} 
ratio decreased to less than one in the later years. The test of $\phi=\rho$ suggests no wage-productivity differentials for the later years. However, it could be misleading to interpret this result as an improvement in gender outcomes in the labor market, as the main factor deriving this result is that female productivity rates are not increasing as fast as their male counterparts. The same pattern holds for domestically-owned firms where the discrimination becomes insignificant in the later years because of a reduction in the relative productivity rates of female workers, along with a slight improvement in their relative wage rates. This is also observed for non-exporters, although their wage-productivity differentials remain significant throughout the period considered in this paper.

State-owned firms, on the other hand, have gender wage ratios that are greater than their gender productivity ratios, indicating that these firms pay a subsidy to their female workers. This result is consistent with the cross-sectional evidence presented in Dong and Zhang (2009) which is based on a much smaller sample covering only five cities in China. In the current paper, using a nationally representative panel survey of firms, allowing simultaneous determination of wage and productivity ratios, and incorporating time-varying coefficients, reveals that the mechanism deriving this result has been changing in favor of male workers. First, the gender wage ratio has been decreasing in SOEs. In 2004, the coefficient, $\phi$, was not significantly different than unity, while it decreased to a level well below unity in later years, implying that female workers are paid less on average than male workers. However, their relative productivity has also been decreasing. In 2004, female workers were 70 percent as productive as male workers, while this ratio decreased to 40 percent by 2007. Table 3 also shows that the growth rates in wage and productivity were not significantly different within SOEs. As a result, SOEs continue to subsidize their female workers at a position where both their relative wages and relative productivity rates are lower than male workers. 
Table 3: Joint Estimation of the Wage Equation and the Production Function - Time Varying $\phi$ and $\rho$

\begin{tabular}{|c|c|c|c|c|c|c|c|c|c|c|c|c|c|}
\hline & $(1)$ & $(2)$ & $(3)$ & $(4)$ & $(5)$ & $(6)$ & $(7)$ & $(8)$ & $(9)$ & $(10)$ & $(11)$ & $(12)$ & $(13)$ \\
\hline & All firms & Domestic & $\mathrm{SOE}$ & $\mathrm{COE}$ & Private & HMT & $\begin{array}{l}\text { Non- Ex- } \\
\text { porter }\end{array}$ & Exporter & $\begin{array}{l}\text { Exporter } \\
1^{s t} \text { Tercile } \\
\end{array}$ & $\begin{array}{l}\text { Exporter } \\
3^{\text {rd }} \text { Tercile } \\
\end{array}$ & FIE & $\begin{array}{l}\text { FIE } 1^{\text {st }} \\
\text { Tercile }\end{array}$ & $\begin{array}{l}\text { FIE } 3^{\text {rd }} \\
\text { Tercile }\end{array}$ \\
\hline \multicolumn{14}{|l|}{ Year: 2004} \\
\hline Gender wage ratio $\phi_{2004}$ & $\begin{array}{l}0.827^{* * *} \\
(82.13)\end{array}$ & $\begin{array}{l}0.768^{* * *} \\
(36.96)\end{array}$ & $\begin{array}{l}1.042^{* * *} \\
(17.15)\end{array}$ & $\begin{array}{l}0.873^{* * *} \\
(19.42)\end{array}$ & $\begin{array}{l}0.825^{* * *} \\
(51.44)\end{array}$ & $\begin{array}{l}0.822^{* * *} \\
(42.15)\end{array}$ & $\begin{array}{l}0.916^{* * *} \\
(53.40)\end{array}$ & $\begin{array}{l}0.774^{* * *} \\
(62.35)\end{array}$ & $\begin{array}{l}0.708^{* * *} \\
(28.08)\end{array}$ & $\begin{array}{l}0.876^{* * *} \\
(40.40)\end{array}$ & $\begin{array}{l}0.718^{* * *} \\
(36.78)\end{array}$ & $\begin{array}{l}0.634^{* * *} \\
(18.46)\end{array}$ & $\begin{array}{l}0.754^{* * *} \\
(23.13)\end{array}$ \\
\hline Test: $\phi_{2004}=1$ & 0.000 & 0.000 & 0.492 & 0.000 & 0.000 & 0.000 & 0.000 & 0.000 & 0.000 & 0.000 & 0.000 & 0.000 & 0.000 \\
\hline Gender productivity ratio $\rho_{2004}$ & $\begin{array}{l}1.238^{* * *} \\
(7.87)\end{array}$ & $\begin{array}{l}1.320^{* *} \\
(2.56)\end{array}$ & $\begin{array}{l}0.700^{* *} \\
(1.99)\end{array}$ & $\begin{array}{l}0.913^{* * *} \\
(3.23)\end{array}$ & $\begin{array}{l}0.891^{* * *} \\
(6.41)\end{array}$ & $\begin{array}{l}0.615^{* * *} \\
(9.12)\end{array}$ & $\begin{array}{l}1.554^{* * *} \\
(4.51)\end{array}$ & $\begin{array}{l}0.818^{* * *} \\
(7.91)\end{array}$ & $\begin{array}{l}0.457^{* *} \\
(2.07)\end{array}$ & $\begin{array}{l}0.848^{* * *} \\
(3.74)\end{array}$ & $\begin{array}{l}0.606^{* * *} \\
(5.04)\end{array}$ & $\begin{array}{l}0.528^{* * *} \\
(3.49)\end{array}$ & $\begin{array}{l}0.314^{* * *} \\
(3.70)\end{array}$ \\
\hline Test: $\rho_{2004}=1$ & 0.131 & 0.113 & 0.392 & 0.157 & 0.431 & 0.003 & 0.108 & 0.078 & 0.014 & 0.026 & 0.001 & 0.006 & 0.000 \\
\hline Test: $\phi_{2004}=\rho_{2004}$ & 0.008 & 0.069 & 0.325 & 0.232 & 0.634 & 0.072 & 0.033 & 0.668 & 0.248 & 0.049 & 0.345 & 0.115 & 0.000 \\
\hline$N$ & 59,663 & 15,161 & 5,830 & 2,775 & 17,046 & 9,957 & 32,101 & 27,562 & 9,188 & 9,187 & 8,894 & 2,965 & 2,965 \\
\hline$R^{2}$ (Wage Equation) & 0.537 & 0.573 & 0.621 & 0.303 & 0.306 & 0.415 & 0.569 & 0.539 & 0.597 & 0.442 & 0.506 & 0.626 & 0.412 \\
\hline$R^{2}$ (Productivity Equation) & 0.927 & 0.940 & 0.951 & 0.888 & 0.843 & 0.839 & 0.926 & 0.930 & 0.948 & 0.904 & 0.880 & 0.915 & 0.862 \\
\hline Correlation of error terms $\epsilon$ & 0.136 & 0.103 & 0.137 & 0.115 & 0.115 & 0.109 & 0.103 & 0.159 & 0.147 & 0.099 & 0.169 & 0.109 & 0.165 \\
\hline \multicolumn{14}{|l|}{ Year: 2005} \\
\hline Gender wage ratio $\phi_{2005}$ & $\begin{array}{l}0.853^{* * *} \\
(89.99)\end{array}$ & $\begin{array}{l}0.776^{* * *} \\
(39.27)\end{array}$ & $\begin{array}{l}0.932^{* * *} \\
(17.96)\end{array}$ & $\begin{array}{l}0.731^{* * *} \\
(17.74)\end{array}$ & $\begin{array}{l}0.907^{* * *} \\
(57.60)\end{array}$ & $\begin{array}{l}0.900^{* * *} \\
(46.18)\end{array}$ & $\begin{array}{l}0.847^{* * *} \\
(57.58)\end{array}$ & $\begin{array}{l}0.821^{* * *} \\
(67.59)\end{array}$ & $\begin{array}{l}0.900^{* * *} \\
(30.88)\end{array}$ & $\begin{array}{l}0.856^{* * *} \\
(43.70)\end{array}$ & $\begin{array}{l}0.741^{* * *} \\
(38.98)\end{array}$ & $\begin{array}{l}0.707^{* * *} \\
(21.36)\end{array}$ & $\begin{array}{l}0.752^{* * *} \\
(23.73)\end{array}$ \\
\hline Test: $\phi_{2005}=1$ & 0.000 & 0.000 & 0.092 & 0.000 & 0.000 & 0.000 & 0.000 & 0.000 & 0.001 & 0.000 & 0.000 & 0.000 & 0.000 \\
\hline Gender productivity ratio $\rho_{2005}$ & $\begin{array}{l}1.513^{* * *} \\
(8.97)\end{array}$ & $\begin{array}{l}1.161^{* * *} \\
(3.88)\end{array}$ & $\begin{array}{l}0.609^{* * *} \\
(3.04)\end{array}$ & $\begin{array}{l}0.635^{* * *} \\
(3.61)\end{array}$ & $\begin{array}{l}1.161^{* * *} \\
(6.15)\end{array}$ & $\begin{array}{l}0.859^{* * *} \\
(7.73)\end{array}$ & $\begin{array}{l}1.363^{* * *} \\
(4.78)\end{array}$ & $\begin{array}{l}0.898^{* * *} \\
(9.72)\end{array}$ & $\begin{array}{l}1.193^{* *} \\
(2.10)\end{array}$ & $\begin{array}{l}0.960^{* * *} \\
(7.04)\end{array}$ & $\begin{array}{l}0.933^{* * *} \\
(6.03)\end{array}$ & $\begin{array}{l}0.883^{* *} \\
(2.47)\end{array}$ & $\begin{array}{l}0.425^{* * *} \\
(4.16)\end{array}$ \\
\hline Test: $\rho_{2005}=1$ & 0.002 & 0.0373 & 0.000 & 0.000 & 0.393 & 0.203 & 0.204 & 0.270 & 0.734 & 0.772 & 0.848 & 0.743 & 0.645 \\
\hline Test: $\phi_{2005}=\rho_{2005}$ & 0.000 & 0.013 & 0.000 & 0.063 & 0.175 & 0.708 & 0.030 & 0.402 & 0.605 & 0.442 & 0.085 & 0.618 & 0.063 \\
\hline$N$ & 62,086 & 15,299 & 5,621 & 2,701 & 18,539 & 10,401 & 33,713 & 28,373 & 9,458 & 9,457 & 9,525 & 3,175 & 3,175 \\
\hline$R^{2}$ (Wage Equation) & 0.485 & 0.545 & 0.570 & 0.279 & 0.238 & 0.359 & 0.518 & 0.492 & 0.546 & 0.450 & 0.433 & 0.588 & 0.354 \\
\hline$R^{2}$ (Productivity Equation) & 0.934 & 0.943 & 0.943 & 0.907 & 0.871 & 0.890 & 0.930 & 0.938 & 0.941 & 0.926 & 0.899 & 0.936 & 0.870 \\
\hline Correlation of error terms $\epsilon$ & 0.124 & 0.105 & 0.105 & 0.076 & 0.115 & 0.141 & 0.114 & 0.127 & 0.111 & 0.099 & 0.167 & 0.175 & 0.162 \\
\hline
\end{tabular}


Table 4 - continued from previous page

\begin{tabular}{|c|c|c|c|c|c|c|c|c|c|c|c|c|c|}
\hline \multicolumn{14}{|l|}{ Year: 2006} \\
\hline Gender wage ratio $\phi_{2006}$ & $\begin{array}{l}0.882^{* * *} \\
(91.70)\end{array}$ & $\begin{array}{l}0.878^{* * *} \\
(41.10)\end{array}$ & $\begin{array}{l}0.820^{* * *} \\
(18.47)\end{array}$ & $\begin{array}{l}1.154^{* * *} \\
(17.13)\end{array}$ & $\begin{array}{l}0.760^{* * *} \\
(57.29)\end{array}$ & $\begin{array}{l}0.885^{* * *} \\
(45.54)\end{array}$ & $\begin{array}{l}0.816^{* * *} \\
(58.62)\end{array}$ & $\begin{array}{l}0.823^{* * *} \\
(68.36)\end{array}$ & $\begin{array}{l}0.913^{* * *} \\
(31.30)\end{array}$ & $\begin{array}{l}0.802^{* * *} \\
(42.00)\end{array}$ & $\begin{array}{l}0.739^{* * *} \\
(40.17)\end{array}$ & $\begin{array}{l}0.694^{* * *} \\
(20.28)\end{array}$ & $\begin{array}{l}0.729^{* * *} \\
(25.11)\end{array}$ \\
\hline Test: $\phi_{2006}=1$ & 0.000 & 0.000 & 0.053 & 0.022 & 0.000 & 0.000 & 0.000 & 0.000 & 0.003 & 0.000 & 0.000 & 0.000 & 0.000 \\
\hline Gender productivity ratio $\rho_{2006}$ & $\begin{array}{l}0.984^{* * *} \\
(10.51)\end{array}$ & $\begin{array}{l}1.261^{* * *} \\
(3.78)\end{array}$ & $\begin{array}{l}0.322^{* * *} \\
(4.13)\end{array}$ & $\begin{array}{l}0.625^{* * *} \\
(2.60)\end{array}$ & $\begin{array}{l}1.009^{* * *} \\
(5.83)\end{array}$ & $\begin{array}{l}1.039^{* * *} \\
(8.36)\end{array}$ & $\begin{array}{l}1.219^{* * *} \\
(5.20)\end{array}$ & $\begin{array}{l}0.808^{* * *} \\
(10.27)\end{array}$ & $\begin{array}{l}0.605^{* * *} \\
(2.75)\end{array}$ & $\begin{array}{l}0.317^{* * *} \\
(7.00)\end{array}$ & $\begin{array}{l}0.448^{* * *} \\
(6.23)\end{array}$ & $\begin{array}{l}0.534^{* * *} \\
(4.58)\end{array}$ & $\begin{array}{l}0.356^{* * *} \\
(4.96)\end{array}$ \\
\hline Test: $\rho_{2006}=1$ & 0.868 & 0.434 & 0.021 & 0.118 & 0.817 & 0.752 & 0.001 & 0.015 & 0.073 & 0.000 & 0.000 & 0.002 & 0.000 \\
\hline Test: $\phi_{2006}=\rho_{2006}$ & 0.272 & 0.249 & 0.017 & 0.029 & 0.012 & 0.207 & 0.012 & 0.850 & 0.161 & 0.000 & 0.000 & 0.184 & 0.000 \\
\hline$N$ & 62,765 & 15,169 & 5,340 & 2,415 & 19,633 & 10,537 & 34,103 & 28,662 & 9,554 & 9,554 & 9,671 & 3,224 & 3,224 \\
\hline$R^{2}$ (Wage Equation) & 0.496 & 0.561 & 0.615 & 0.314 & 0.258 & 0.331 & 0.525 & 0.500 & 0.578 & 0.404 & 0.423 & 0.593 & 0.332 \\
\hline$R^{2}$ (Productivity Equation) & 0.934 & 0.943 & 0.943 & 0.907 & 0.871 & 0.890 & 0.930 & 0.938 & 0.941 & 0.926 & 0.899 & 0.936 & 0.870 \\
\hline Correlation of error terms $\epsilon$ & 0.944 & 0.945 & 0.962 & 0.936 & 0.888 & 0.905 & 0.937 & 0.948 & 0.956 & 0.918 & 0.908 & 0.916 & 0.930 \\
\hline \multicolumn{14}{|l|}{ Year: 2007} \\
\hline Gender wage ratio $\phi_{2007}$ & $\begin{array}{l}0.938^{* * *} \\
(90.33)\end{array}$ & $\begin{array}{l}0.929^{* * *} \\
(41.04)\end{array}$ & $\begin{array}{l}0.852^{* * *} \\
(16.96)\end{array}$ & $\begin{array}{l}0.900^{* * *} \\
(15.70)\end{array}$ & $\begin{array}{l}0.903^{* * *} \\
(53.87)\end{array}$ & $\begin{array}{l}0.881^{* * *} \\
(43.29)\end{array}$ & $\begin{array}{l}0.769^{* * *} \\
(59.41)\end{array}$ & $\begin{array}{l}0.887^{* * *} \\
(64.58)\end{array}$ & $\begin{array}{l}0.911^{* * *} \\
(29.83)\end{array}$ & $\begin{array}{l}0.929^{* * *} \\
(42.85)\end{array}$ & $\begin{array}{l}0.868^{* * *} \\
(40.11)\end{array}$ & $\begin{array}{l}0.812^{* * *} \\
(20.80)\end{array}$ & $\begin{array}{l}0.955^{* * *} \\
(25.91)\end{array}$ \\
\hline Test: $\phi_{2007}=1$ & 0.000 & 0.002 & 0.003 & 0.081 & 0.000 & 0.000 & 0.000 & 0.000 & 0.004 & 0.001 & 0.000 & 0.000 & 0.222 \\
\hline Gender productivity ratio $\rho_{2007}$ & $\begin{array}{l}0.885^{* * *} \\
(11.65)\end{array}$ & $\begin{array}{l}1.202^{* * *} \\
(3.20)\end{array}$ & $\begin{array}{l}0.403^{* * *} \\
(3.35)\end{array}$ & $\begin{array}{l}0.202 \\
(1.36)\end{array}$ & $\begin{array}{l}1.301^{* * *} \\
(6.90)\end{array}$ & $\begin{array}{l}0.476^{* * *} \\
(11.87)\end{array}$ & $\begin{array}{l}1.154^{* * *} \\
(4.18)\end{array}$ & $\begin{array}{l}0.694^{* * *} \\
(11.44)\end{array}$ & $\begin{array}{l}0.675^{* * *} \\
(3.09)\end{array}$ & $\begin{array}{l}0.977^{* * *} \\
(8.43)\end{array}$ & $\begin{array}{l}0.631^{* * *} \\
(7.06)\end{array}$ & $\begin{array}{l}0.664^{* * *} \\
(3.55)\end{array}$ & $\begin{array}{l}0.483^{* * *} \\
(5.39)\end{array}$ \\
\hline Test: $\rho_{2007}=1$ & 0.129 & 0.591 & 0.015 & 0.000 & 0.111 & 0.000 & 0.152 & 0.000 & 0.136 & 0.844 & 0.000 & 0.073 & 0.000 \\
\hline Test: $\phi_{2007}=\rho_{2007}$ & 0.480 & 0.467 & 0.028 & 0.000 & 0.004 & 0.000 & 0.021 & 0.238 & 0.275 & 0.674 & 0.007 & 0.416 & 0.000 \\
\hline$N$ & 60,985 & 14,395 & 5,026 & 2,138 & 19,470 & 10,582 & 34,007 & 26,978 & 8,993 & 8,992 & 9,374 & 3,125 & 3,125 \\
\hline$R^{2}$ (Wage Equation) & 0.476 & 0.536 & 0.612 & 0.376 & 0.266 & 0.359 & 0.501 & 0.468 & 0.522 & 0.457 & 0.420 & 0.533 & 0.409 \\
\hline$R^{2}$ (Productivity Equation) & 0.945 & 0.947 & 0.960 & 0.937 & 0.897 & 0.909 & 0.930 & 0.954 & 0.961 & 0.930 & 0.922 & 0.932 & 0.936 \\
\hline Correlation of error terms $\epsilon$ & 0.138 & 0.061 & 0.163 & 0.086 & 0.130 & 0.175 & 0.114 & 0.172 & 0.126 & 0.157 & 0.213 & 0.263 & 0.183 \\
\hline
\end{tabular}


In Table 2, we found that that the gender wage-productivity differentials are not significant among exporters. Allowing the coefficients to vary over time also reveals that this result holds for each year across the export ratio spectrum, with the exception of the $3^{\text {rd }}$ tercile in 2004 and 2007. However, both ratios increased substantially among the $1^{\text {st }}$ tercile of exporters, with the wage ratio increasing from 70 percent to 91 percent, and the productivity ratio increasing from 46 percent to 67 percent. These firms, as a result, continued to pay female workers their relative marginal product, with improved relative wages and relative productivity levels. This is the mirror image of the changes in SOEs, where both indicators have deteriorated. It is important to note that the gender wage gaps among exporters are significant, and female workers received average wages around 80 percent of male workers' wages. The discrimination test, on the other hand, is rejected, implying that the relative wages of female workers are, in fact, equivalent to their relative marginal product.

The results for foreign invested enterprises are presented in the last three columns of Table 4. Firms with a large amount of foreign capital (within the $3^{\text {rd }}$ tercile) pay their female workers a relative wage that is well above their productivity level for each year. For example, in 2004, the gender wage ratio was 75 percent while the gender productivity ratio was only 31 percent. By 2007, the average wage rates of female workers equalized to the average wages of male workers, as we are not able to reject the hypothesis of $\phi=1$, while the gender productivity ratio was only 48 percent. On the other hand, firms in the $1^{\text {st }}$ tercile of the share of foreign capital paid female workers relative wages that are equivalent to their relative productivity. When we consider all foreign-invested firms, we find that the gender wage ratio has been increasing much faster than the gender productivity ratio, and the wage-productivity differentials has have become more significant over time. As a result, these firms continue to pay their female workers wage premiums.

\section{Conclusion}

The impact of globalization on gender wage discrimination has been a controversial subject in the literature due to the conflicting evidence documented for many different countries. This is not surprising, however, as the channels through 
which male and female workers are affected by globalization may be influenced by the factor content of international trade, the relative human capital advantages of female workers, the initial composition of trade protection, the market structure, the government regulations in both the labor market and at the industry-level, and by many other country-specific factors. Therefore, it is not even possible to generalize one particular finding in the literature across all developing countries. The previous research on China has been especially restrictive because of the limited data availability, with the most sophisticated studies having been based on small cross-sectional surveys that cannot be interpreted as population-wide evidence.

In this paper, we analyze the gender wage-productivity differentials of exporting and foreign-invested Chinese enterprises. These analyses are based on a rich, nationally representative panel survey that follows approximately 60,000 firms for four recent years between 2004 and 2007. While the information in this data does not allow for the direct estimation of Blinder-Oaxaca type decompositions, we instead use a methodology which tests the significance and direction of the gender wage gaps, the gender productivity gaps, and the discrimination for each firm category over time. The panel aspect of this survey allows us to analyze how the wage-productivity differentials have evolved over time, and also to identify the source of this variation in order to understand whether the result is driven by an improvement or deterioration in the gender outcomes.

An important consideration within this framework is that the wage and productivity outcomes in a labor market cannot be considered independent of one another. On the supply side, higher wage levels can increase worker productivity by providing greater incentives, thereby changing the structure of labor supply, or by directly affecting worker productivity, as suggested by the efficiency wage theory. On the demand side, productivity is expected to influence the relative wages in competitive markets, as a firms employment level is determined where the wage rate is set equal to the value of marginal product of labor. The positive interdependence between these two mechanisms could bias the estimates for the gender wage-productivity differentials downwards, leading to the conclusion of no differentials between these groups, even in cases where there are in fact significant gaps.

The methodology in this paper is based on a series of simultaneous nonlinear regressions estimated with nonlinear least squares. We estimate this model by as- 
suming constant coefficients, time-varying coefficients, and by allowing differential growth rates across firms. The results suggest that the relative wages of female workers among exporting and foreign-invested firms have been either equivalent to or higher than their relative productivity. We do not find evidence of discrimination in the form of wage-productivity differentials among these firms across the distributions of export intensity or the share of foreign investment. On the other hand, strong evidence of discrimination has been found among domesticallyoriented firms and non-exporters.

This paper contributes to the greater body of literature on the subject by providing comprehensive evidence that globalization is not associated with higher gender wage-productivity differentials for the manufacturing sector in China. The exporting and foreign-invested firms tend to pay female workers at least their relative marginal product. However, the average wages among female workers are lower across the country with the exception of state-owned firms. This disparity could be reduced with strategies that increase the relative productivity of female workers, such as the provision of incentives for higher investment in their human capital that will move the female labor force from unskilled to skilled occupations.

\section{References}

[1] Abowd, J., Kramarz, F. and Margolis, D. 1999. "High Wage Workers and High Wage Firms," Econometrica, 67(2): 251-334.

[2] Altonji, J. and Blank, R. 1999. In: Ashenfelter, O., Card, D. (Eds.) "Race and Gender in the Labor Market," Handbook of Labor Economics, Vol. 3c: 3144 -3213, Elsevier Science, North Holland.

[3] Attanasio, O., Goldberg, P. and Pavcnik, P. 2004. "Trade Reforms and Wage Inequality in Colombia," Journal of Development Economics, 74(2): 331-366.

[4] Becker, G.S. 1957. The Economics of Discrimination, 2nd ed. Chicago, Ill.: University of Chicago Press.

[5] Benito, A., 2000. "Interindustry Wage Differentials in Great Britain," Oxford Bulletin of Economics and Statistics, 62(0): 727-746.

[6] Berik, G., Rodgers, Y. and Zveglich Jr., J., 2004. "International Trade and Gender Wage Discrimination. Evidence from East Asia," Review of Development Economics, 8(2): 237254 . 
[7] Bishop, J., Luo, F. and Wang F., 2005. "Economic Transition, Gender Bias, and the Distribution of Earnings in China," Journal of Economic Transition, 13, 239-259.

[8] Black, S.E., and Brainerd, E., 2004. "Importing Equality? The Impact of Globalization on Gender Discrimination," Industrial and Labor Relations Review, 57(4): 540-559.

[9] Brandt, L., Van Biesebroeck, J., and Zhang, Y., 2012. "Creative Accounting or Creative Destruction? Firm-Level Productivity Growth in Chinese Manufacturing," Journal of Development Economics, 97: 339-351.

[10] Braunstein, E., 2006. "Foreign Direct Investment, Development and Gender Equity: A Review of Research and Policy," UNRISD Working Paper Series, No: 2006-12.

[11] Busse, M., and Spielmann, C., 2006. "Gender Inequality and Trade," Review of International Economics, 14(3): 362-379.

[12] Chan, A., 2003. "A Race to the Bottom: Globalization and China's Labour Standards," China Perspectives, 46: 41-50.

[13] Cling, R, and Roubaud, A. 2005. "Export Processing Zones in Madagascar: A Success Story under Threat?," World Development, 33(5): 785-803.

[14] Cohen, B., and William J. H., 1993. "Women's Urban Labour Market Status in Developing Countries: How Well Do They Fare in Khartoum, Snaan," Journal of Development Studies, $29(3): 461-483$.

[15] Currie, J., and A. Harrison, 1997. "Sharing the Costs: The Impact of Trade Reforms on Capital and Labor in Morocco," Journal of Labor Economics, 17(3): S44-S71.

[16] Dong, X. and Zhang, L., 2009. "Economic Transition and Gender Differentials in Wages and Productivity: Evidence from Chinese Manufacturing Enterprises," Journal of Development Economics, 88: 144-156.

[17] Feliciano, Z., 2001. "Workers and Trade Liberalization: The Impact of Trade Reforms in Mexico on Wages and Employment," Industrial and Labor Relations Review, 55(1): 95-115.

[18] Fontana, M. and Wood, A, 2000. "Modeling the Effects of Trade on Women, at Work and at Home," World Development, 28(7): 1173-1190.

[19] Galiani, S. and Porto, G., 2010. "Trends in Tariff Reforms and in the Structure of Wages," Review of Economics and Statistics, 92(3): 482-494.

[20] Gao, H., Marchand, J. and Song, T., 2013. "The Supply and Demand Factors Behing the Relative Earning Increases in Urban China at the Turn of the 21st Centrury," Comparative Economics Studies, forthcoming.

[21] Goldberg, P. and Pavcnik, N., 2005. "Trade, Wages, and the Political Economy of Trade Protection: Evidence from the Colombian Trade Reforms," Journal of International Economics, 66(1): 75-105. 
[22] Goux, D. and Maurin, E., 1999. "Persistence of Interindustry Wage Differentials: A Reexamination Using Matched Worker-Firm Panel Data," Journal of Labor Economics, 17(3): 492-533.

[23] Gustafsson, B. and Shi, L. (2000). "Economic Transformation and the Gender Earnings Gap in Urban China," Journal of Population Economics, 13(2), 305-329.

[24] Harrison, A. and Hanson, G. 1999. "Who Gains from Trade Reforms? Some Remaining Puzzles," Journal of Development Economics, 59(1): 125-154.

[25] Hellerstein, J., Neumark, D. 1998. "Wage Discrimination, Segregation, and Sex Differences in Wage and Productivity within and Between Plants," Industrial Relations, 37: 232-260.

[26] Hellerstein J. and Neumark D., 1999a. "Sex, Wages, and Productivity: An Empirical Analysis of Israeli Firm-Level Data," International Economic Review, 40(1): 95-123.

[27] Hellerstein J., Neumark D. and Troske K., 1999b. "Wages, Productivity, and Worker Characteristics: Evidence from Plant-Level Production Function and Wage Equations," Journal of Labor Economics, 17(3): 409-446.

[28] Joekes, S. 1995. "Trade-Related Employment For Women In Industry And Services In Developing Countries," UNRISD Working Paper Series, No: 1995-5.

[29] Knight, J. and Song, L., 2003. "Increasing Urban Wage Inequality in China," Economics of Transition, 11(4): 597-619.

[30] Liu, P., Meng, X. and Zhang, J.S., 2000. "Sectoral Gender Wage Differentials and Discrimination in the Transitional Chinese Economy," Journal of Population Economics, 13: 311-352.

[31] Malchow-Mller, N., Markusen, J. and Schjerning, B., 2009. "Foreign Firms, Domestic Wages," CAM Working Papers, No: 2009-02, University of Copenhagen, Centre for Applied Microeconometrics.

[32] Maurer-Fazio, M., Rawski, T.G., Zhang,W., 1999. "Inequality in the Rewards for Holding up Half the Sky: Gender Wage gaps in China's Urban Labor Market, 1998-1994," China Journal, 41: 55-88.

[33] Menon, N. and Rodgers, Y., 2008. "International Trade and Gender Wage Gap: New Evidence from India's Manufacturing Sector," World Development, 37(5): 965-981.

[34] Mitra, D. and Ural, B., 2008. "Indian Manufacturing: A Slow Sector in a Rapidly Growing Economy", The Journal of International Trade 85 Economic Development, 17(4): 525-559.

[35] Nicita, A. and Razzaz, S., 2003. "Who Benefits and How Much? How Gender Affects Welfare Impcats of a Booming Textile Industry?," World Bank Policy Research Working Paper, No: 3029.

[36] Nordas, H. K., 2003. "The Impact of Trade Liberalization on Women's Job Opportunities and Earnings in Developing Countries," World Trade Review, 2(2): 221-231. 
[37] Oostendorp, R. 2009. "Globalization and the Gender Wage Gap," World Bank Economic Review, 23(1): 141-161.

[38] Ozler, S., 2000. "Export Orientation and Female Share of Employment: Evidence from Turkey," World Development, 28(7): 1239-1248.

[39] Pavcnik, N, 2003. "What Explains Skill Upgrading in Less Developed Countries?," Journal of Development Economics, 71(2): 311-328.

[40] Revenga, A., 1997. "Employment and Wage Effects of Trade Liberalization: The Case of Mexican Manufacturing," Journal of Labor Economics, 15 (3): S20-S43.

[41] Robertson, R., 2004. "Relative Prices and Wage Inequality: Evidence from Mexico," Journal of International Economics, 64(2): 387-409.

[42] Rozelle S., Dong X., Zhang L. and Mason A., 2002. "Gender Wage Gaps in Post-Reform Rural China," Pacific Economic Review, 7(1), 157-179.

[43] Segiuno, S., 1997. "Gender Wage Inequality and Export-Led Growth in South Korea," Journal of Development Studies, 34(2): 102-132.

[44] Shu, X.L. and Bian, Y.J., 2003. "Market Transition and Gender Gap in Earnings in Urban China, " Social Forces, 81(4), 1107-1145.

[45] Standing, G. 1999. "Global Feminization through Flexible Labor: A Theme Revisited," World Development, 27(3): 583-602.

[46] Ural, B, Horrace, W. and Jung, J.H., 2009. "Inter-Industry Gender Wage Gaps by Knowledge Intensity: Discrimination and Technology in Korea," Applied Economics, 41: 14371452 .

[47] Xu, W., Tan, K.C. and Wang, G.X., 2006. "Segmented Local Labour Markets in Postreform China: Gender Earnings Inequality in the Case of Two Towns in Zhejiang Province," Environment and Planning, 38, 85-109.

[48] Whalley, J. and Xin, X. 2010. "China's FDI and Non-FDI Economies and the Sustainability of Future High Chinese Growth," China Economic Review, 21(1): 123-135.

[49] Wellington, A., 1993. "Changes in the Male/Female Wage Gap, 1976-85," Journal of Human Resources, 28(2): 383-441.

[50] Wood, A., 1991. "North-South Trade and Female Labour in Manufacturing: An Asymmetry," Journal of Development Studies, 27(2): 168-189.

[51] Zhihong, C., Ying, G., Huiwen L. and Wan, C., 2012. "Globalization and Gender Wage Inequality in China, " Mimeo. 